\title{
New Methodologies on the Improvement of Public Administration in Uzbekistan
}

\author{
Raximova Mukaddas Ibragimovna
}

\begin{abstract}
This article discusses the concept of public administration, its features: the problem of state and municipal government. The fundamental and modern technologies of social management are analyzed. The theoretical and important aspects of the development of public administration are revealed.

The author substantiates the development of a program to ensure an effective dialogue with the people as a means of implementing the principles of humanism and measures for the implementation of topical government tasks put forward in five directions of the development strategies of the Republic of Uzbekistan
\end{abstract}

The requirement of the head of state that "not the people serve the state bodies, but the state bodies must serve the people" will require in society stability of the principle of social justice, ensuring equality of all before the law, achieving the rule of law, analyzes the needs of parliament for talented, ambitious, competent representatives of parliament. Uzbekistan is in the process of reforming all spheres of public life, there are fundamental changes in the minds of citizens, democratic forms the formation of society - a simplified order of relations between people and society, a citizen and a state.

There is a social and political activity in the country. In such conditions, rapid reforms of public administration, introduction of new approaches and tendencies to management based on the use of wide possibilities of information technologies are important.

The article considers that if administrative staff representing the interests of civil society, first of all, understand the personal, general and specific historical and socio-political situation of the entire population of the country, and the state and society are nationalized, this can be viewed as a sufficient form of an open society, impartiality truthfulness and timeliness to meet the needs of people.

Keywords : State, administration, citizinship, mechanism, principles, reforms, democratization, innovation, modernization, optimization, implimentation.

\section{INTRODUCTION}

A necessary condition for the strengthening and development of governmental authority is the law rule, the uniform and unswerving performance of laws that are issued by state bodies and functionaries as well as citizens and public organizations. Thus, the government is among the necessary and special means for governing the country, adopting and enforcing laws designed to regulate relations both in the state and at the international level.

Famous scientists who study political reform and

Revised Manuscript Received on October 15, 2019.

* Correspondence Author

Raximova Mukaddas Ibragimovna, PhD studen, Uzbekistan State University of World Languages, Tashkent, Uzbekistan. democratic change in society and the government propagate the idea that the effectiveness of reforms in any society depends, first of all, on the maintenance of peace and stability in the country. Indeed, the development of society and the correct implementation of the reforms will depend first of all on the peace and stability, and on the continuity of the reforms. This idea can be supplemented by the following phrase: if the state takes the interest of the people, gives it liberties in public affairs, business and social life, the government is democratic and leads to progress.

The most important priority of the current stage of large-scale reforms in Uzbekistan is to improve public administration, to ensure publicity of public administration and to optimize the governance system $[8,19]$. The essence of the reforms is to promote the practical application of the principle that human interests are superior to everything and, above all, to communicate directly with the people.

\section{RESEARCH METHODOLOGY}

The scientific method is used in all sciences-including political and sociological sciences. The scientists in these fields ask different questions and perform different tests. However, they use similar core approaches to find answers that are logical and supported by evidence.

During this research we tried to review the reforms of the political process in the country, and made attempts to analyze the topic by making observations. We also used comparative analysis method.

\section{RESEARCH ANALYSES}

Thanks to independence, democratic reforms have been carried out in our country, and the system of public administration and governance has been radically updated on the basis of democratic principles. These processes are reflected in the work of social scientists. Until now, what is written on this topic can be divided into two groups. In one group, this problem has been studied together with reforms in all spheres of the country's socio-political life, while the other group analyzed specifically the reforms in the field of public administration and governance. For example, the book "Independence: Definitive Scientific - Popular Glossary" (T. "Sharq" - 2006), "Commentary on the Constitution of the Republic of Uzbekistan", "The Great and Holy Mother of Independent Homeland" (T., "Teacher" (T., "Uzbekistan", 2008), in his books; B.Berdiev's "Real Steps to Reform the Political System in Uzbekistan" (Journal of Democracy and Human Rights, 2007), B. Mirbaev's book "Public Administration and Governance" 
(Journal of Rights and Obligations, 2011, issue 3), S.Raupov's article "Constitutional Reforms - Guarantee of Democracy" (Scientific Reports of the University, 2011) were analyzed and investigated. We studied all of these publications and tried to use them as creative.

\section{ANALYSES AND DISCUSSIONS}

Each stage has its own developmental factors, needs, requirements and vital principles. Every era has its own minds, views, attitudes and thinking styles. From this perspective we can say that 2017 has begun a new stage in the historical development and development of Uzbekistan. It is associated with strong, powerful, and powerful political thinking, synthesized by the indigenous, modern, global, state-of-the-art experience of world civilization that meets modern civilization requirements [3, 7]. ].

It requires a deep knowledge of public administration and its essence, and a broader understanding. For this purpose, it is important to mention the following definition of public administration:

Public administration is the political activity of the state aimed at the organization of social relations aimed at the protection of the state's interests, which is the implementation of the daily management of public authorities and officials in economic, social, cultural, administrative and political areas the full implementation of the program. Consequently, public administration activities traditionally coincide on the one hand political activities and, on the other, activities that form the political course $[5,180]$. From a modern point of view, the management of the period of the state power system's development, the form of public administration as a factor of co-operation is envisaged.

Importantly, the essence, style and style of public administration are determined by the historical conditions of national cultural and socio-political development of the society, the peculiarity of the political and legal culture of the people, the professionalism and will of the ruling elite, the form and the political order of the state. However, the impact of the external environment requires each state to reform its administrative system that meets the changing global challenges. These changes lead to the reduction of government expenditures in the market economy and the implementation of public functions. It also promotes the quality of public services, building a full-fledged civil society, and, in the majority of the population, the confidence in public authorities [2]. In other words, this is about the importance of studying the theoretical and practical aspects of this topic in the theory of today.

In scientific literature, the factors of management are diverse and, accordingly, they are understood differently. This is not only a variety of approaches, but also the essence and meaning of the concept of governance. In the most appropriate way, the essence of the management can be fully explained by the term "effective management", that is, stimulating, changing, compelling and changing the mind, movement and activities of people. Unlike ordinary effects, managerial effect involves more than one key element: concepts and analyzes, setting goals, organizing, coordinating, organizing, monitoring, evaluating results and planning new steps $[4,366]$.
Thus, the administration is, in addition to direct self-governance, a specific, state-economic, political-party, socio-community structure of institutions specifically planned, organized and created. Public administration plays a special role in all forms of governance. It is connected with the fact that public administration, on the one hand, is a mechanism that carries out the targeted leadership of the state in society and all its sub-systems. On the other hand, it is a type of law enforcement, law enforcement, and educational and educational activity in the exercise of its legislative, executive, judicial or other powers. In addition, the term "public administration" also describes the field of the theory of scientific knowledge.

The scientific object of state administration consists of various departments of the state and government apparatus, municipal, public administration bodies, institutes and systems. It also describes the nature of objective-subjective relationships in the narrow and narrow sense of public administration.

In a broad sense, public administration is the governance of the society, which is governed by all branches of government as well as by the self-governing bodies. Public administration is narrower - it is the activity of the executive in the conduct of community activities through the proper enforcement, instruction and control. In this sense, public administration has a clear, decent, coordinating and regulatory character $[6$, 640].

Despite the distinctive features of public administration in different countries, we can emphasize the global trends in generalizing the general principles and approaches in public administration. But the adaptation of these models is not the same. In many countries, the ruling elite is interested in maintaining its status. Because they are based on the sustainability of their position and the economic benefits associated with it. We often hear that governments in different countries have specific features because of cultural factors. Moreover, public administration is firmly bound to political and legal processes. Actually, the differences are huge. However, simple surveillance not only shows the similarity of government models in the modern world, but also in the history of mankind. Of course, the characteristic feature is also remarkable. But the common features behind them are hidden. As the need for changes in society changes, public administration will also change. However, cooperation in public administration can be observed in the context of globalization. Today, the whole system serves not only one country, but the entire world community, and the need for public administration depends on the causes created by the state itself.

One of the reasons for the emergence of an organization called a state with a special office apparatus is the need for it. However, at a certain stage of social development, earlier, the sowing community did not fully comply with the traditional forms of social management and the "general affairs" of society. Today, when our society is at the stage of improvement, problems become more complicated, management work increases, and its specialization is diversified. These types of organizations will set forth important priorities for dealing with "common affairs" [1, 157]. 
At the present time, all developed countries, despite natural differences, are now reaching the only conclusion that the fruits of this society can achieve a decent standard of living by arranging the management of society. In this regard, it can be concluded that the need for public administration is related to the need to ensure the effective implementation of natural, labor, material and information resources, fair redistribution of income and the provision of basic social rights and the implementation of public policies for the maintenance of public order.

Today's achievement of Uzbekistan is underpinned by the peculiarities of state governance in the country, the form of ownership of state-owned forms of production from a single socio-economic system, various forms of ownership in the market economy, democratic mechanisms of governance, and civil society principles. The laws, decrees and decisions that have been adopted bring new impetus and direction to the great change [12,7].

After the Presidential elections in Uzbekistan on December 4,2016 , the main principle derived from the fundamental requirement for building a solid foundation of the people's state, expanding democratic possibilities, acting as an independent power of legislative, executive and judicial powers - the issue of settlement has been put on the agenda. If the state pursues the interests of the people and gives it liberties in government, business, and social life, it is a democratic state that promotes the development of a peace policy.

Thus, in the work and working style of the head of the Uzbek government Sh.M.Mirziyoev there is a sense of folk management, the sense of being close to the people, the sense of their common anxiety and joy. This leads to the state and the society, the head of state and the common goal of citizenship, to the harmony between them, which in turn promotes the consolidation of the overall stability and high creative spirit in Uzbekistan. From that point of view we can say with certainty that "we will build our great future with our noble and courageous people ..." [3, 6].

In this regard, President of the Republic of Uzbekistan Shavkat Mirziyoyev said in his speech to the 72nd session of the UN General Assembly that deep and comprehensive reforms are being carried out in all spheres of Uzbekistan and implementation of the principle "Human interests above all things" through the impressive mechanisms, but the government should serve the people $[11,25]$.

Of course, the support of the current rapid development process in Uzbekistan, as a democratic way of governance, will allow optimizing the legal norms of khokimiyats' authorities and, in the performance of their duties, to make independent decisions based on legal requirements and local conditions. All of this means that the society of Uzbekistan has begun a completely new era of quality in practice.

At the same time, the issue of the need for modernization of public administration, aimed at enhancing the responsibility of the public administration on optimization of quality and impartiality of the population, remains a top priority. Modernization can succeed only if there is no contradiction between general and specific goals and benefits, given the human factor at present $[10,20]$.

The draft Decree of the President of the Republic of Uzbekistan "On the Strategy for the Further Development of the Republic of Uzbekistan" was elaborated on the basis of concentration, in-depth study and generalization of proposals from the local population in the new historical conditions created in Uzbekistan, and a wide range of discussions were held among the population. In practice there was no legal entity - Virtual Reception of the President of the Republic of Uzbekistan and the Presidential Palace of the Republic of Uzbekistan.

Over 310 proposals and comments were received on the results of the public discussion on the portal of the Legislative Impact Assessment System of the project, on which 41 items of the State Program were revised. Media-weekly and international roundtables were organized as well [9, 41].

A simple, straightforward, popular principle of building a just and humanist society, developed by the President of the Republic of Uzbekistan Sh.M.Mirziyoev, in the five directions of further development of the Republic of Uzbekistan, was put forward. Measures to implement the most important and urgent tasks of the principle of nationalism have been developed to ensure effective communication with the people. Nowadays, our work is to make sure that the mechanisms for communicating with the people are constantly functioning. The most important thing is that there is a need for a parliamentary coalition that is eager to take the country to the fullest extent possible in the pursuit of full-fledged, talented, legislative and representative responsibilities.

\section{DATA ANALYSES}

The requirement that the head of the state "not to public authorities but public authorities should serve the people" will lead to the principles of social justice, the rule of law, and equality before the law $[3,26]$.

The table below lists the applicants for the monitoring of applications submitted during the year to the Virtual Lounge of the President of the Republic of Uzbekistan. According to it, the main group (52\%) of the applicants was employed, followed by unemployment (29\%), retirees (17\%) and students $(2 \%)$.

Virtual lounge of the President of the Republic of Uzbekistan classification of applicants

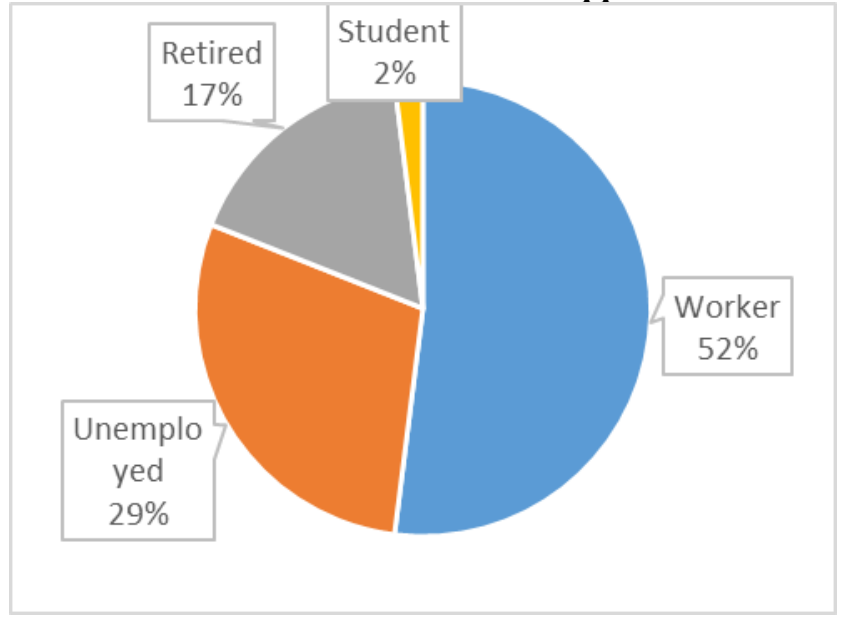

Source: Scientific-popular guide to the study of the appeal of Shavkat Mirziyoev, the President of the Republic of Uzbekistan, to the Oliy Majlis of the Republic of Uzbekistan and 
dissemination to the general public. Ministry of Higher and Secondary Specialized Education of the Republic of Uzbekistan. 2018.42-p. Picture 3.3.

In this table, the Virtual Lobby of the President of the Republic of Uzbekistan contains statistical data on what public access by mass media:

Source: Scientific-popular guide to the study of the appeal of Shavkat Mirziyoev, the President of the Republic of Uzbekistan, to the Oliy Majlis of the Republic of Uzbekistan and dissemination to the general public. Ministry of Higher and Secondary Specialized Education of the Republic of Uzbekistan. 2018.45-p. Picture 3.6
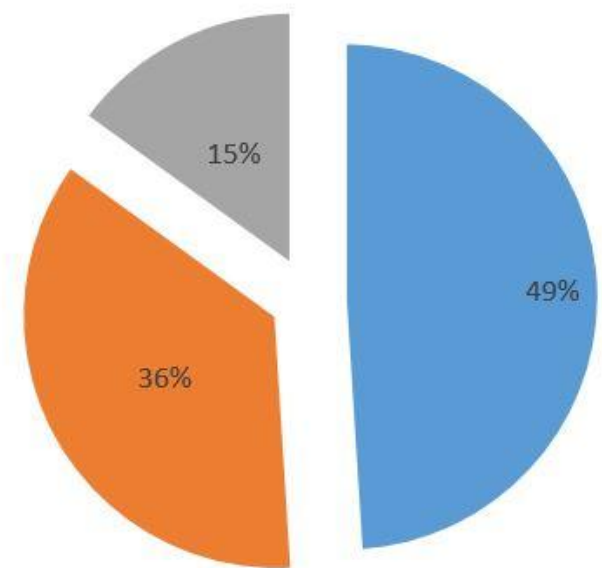

- hotline Web page National reception

It is worth noting that, in order to create conveniences for the citizens of the country, there is a tendency of systematic visits, monitoring of activities of sectors. Another important aspect is that citizens come to the People's Libraries not only with their problems, but also to the development of the regions and to improve the living conditions of the people. This shows that our compatriots are increasingly concerned about the country's prosperity and the wellbeing of our people.

The following two tables illustrate the sexual content of those applying to the Virtual Lounge

\section{Virtual lounge of the President of the Republic of Uzbekistan classification of applicants}

Won Область диаграммы

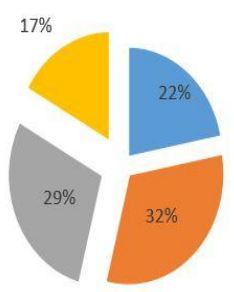

- Worker " Unemployer " Retired " Student

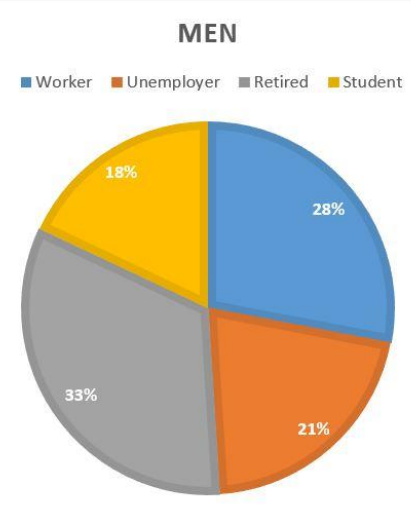

Source: Scientific-popular guidebook of the President of the Republic of Uzbekistan Shavkat Mirziyoev to the Oliy Majlis of the Republic of Uzbekistan and the popularization of the general public. The Ministry of Higher and Secondary Specialized Education of the Republic of Uzbekistan. 2018.42-p. Picture 3.4.

Today, the process of reforming all spheres of social life in Uzbekistan, fundamental changes in the minds of the citizens, democratic forms of society - the simplified order of relations between people and society, citizen and state.

The activity in the social and political spheres of the country has become more active. And most importantly, there is a general belief that if the people are actively involved in the ongoing reforms, relying on the will of the people, if people realize the essence of radical change and support the reforms, the realization of the goals and objectives of modernization and renovation in the country will surely come true $[10,46]$. This is one of the factors of the new political mechanism in the development of public administration and the development of the political system. According to him, the demand for the day requires that there is a need for a parliamentary coalition that is eager to carry out its responsibilities in the country with full functioning, talented, legislative and representative responsibilities.

The role of public administration in ensuring rationality, that is, the consistency, viability, effectiveness and sustainability of governance play an important role in ensuring social security, public control over the public administration and the development of net prospect plans. These factors, which have made a major breakthrough in the socio-political life of our country, have resulted in a new era of public administration in the organization of people's dormitories.

Democratization of public administration, first of all, requires a relationship of trust, mutual understanding, sincerity and integrity between the state and citizens, between state bodies and all state systems. It requires a fair trial between state and law enforcement.

\section{CONCLUSION}

In short, this is about a broad democratization of public administration, and in this process, democratization will have a foundation for socially free and productive activities for the citizens of the country when they have a stable place in society. According to the President of the country Sh.Mirziyoev, the main goal of these reforms is to ensure the quality and quality of life for 
the population, and the noble idea that "the interests of mankind are superior to everything" should be pursued consistently. However, the two-year work experience of the Presidential lobby has shown that in the recent past we have been far away from the people, its concerns and problems [8, 26].

If civil servants understand the individual, shared and specific historical and socio-political status of the whole population of the country, and if the government and society are publicized, then management can be considered as a sufficient form of an open society; Secondly, impartiality and timely representation of the relevance and priority of the interests of the population - contributes to the practical realization of interests and will really satisfy the needs of the people.

It is possible to conclude from the above points that the requirements of democracy, human interests, and society's government are quite high. Of course, society wants to see public management as socially productive. Reminds you of the need to introduce intuitive management based on objective and subjective factors that will enable you to effectively address social problems and ensure consistent development of society.

\section{REFERENCES}

[1] Atamanchuk, G.V. Public Administration Theory: Textbook / M : "Omega-L", 2010.

[2] 2. Public and Municipal Service: Methodology, Theory, Practice, and Korean Experience. Rostov n / d., 1997.

[3] 3. Jo'raev appealed to Tabanaddin (Commentaries on the Shirin Mirziyayev's Intensive Development Strategy). Tashkent. "Uzbekistan" 2018 .

[4] 4. Kozbanenko V. A. Public Administration: Textbook. M: "Status", 2002 .

[5] 5. Malysheva M.A. Theory and method of public administration. Educational-methodical manual. - SPb .: NIU VShE Rapid printing department-Saint-Petersburg, 2011. 180.

[6] 6. Pikulkin A.V. Public administration system. M., 1997.

[7] 7. Shernazarov A. There is human dignity behind every appeal // "Khalq Suzi" newspaper. November 22, 2017.

[8] 8. Application to the Oliy Majlis on the most important priorities of the President of the Republic of Uzbekistan for 2019. December 22, 2017 T., "Uzbekistan", 2018.

[9] 9. Conducted by the President of the Republic of Uzbekistan Shavkat Mirziyoev to study the appeal of the Oliy Majlis and popularization among the general public. Science-popular guide. Ministry of Higher and Secondary Special Education of the Republic of Turkey. Tashkent, "Spirituality", 2018.

[10] 10. Political reform process in Uzbekistan. Academy of Public Administration under the President of the Republic of Uzbekistan. Tashkent. "Academy", 2011.

[11] 11. Statement of the President of the Republic of Uzbekistan Shavkat Mirziyayev at the 72nd session of the UN General Assembly. // http://uzbekistan24.uz. 20.09.2017

[12] Toward intensive progress and renewal based on the strategy of action. The brochure. - T., publishing and printing house named after Gafur Gulom. 2017 